were not quite realised on further perusal. M. Micé wrote this report at the request of the Societé des Sciences Physiques et Naturelles, who purpose publishing similar reports annually. The title, it will be perceived, is perfectly general and it might have attracted any student of organic chemistry. But the author informs us (p. I) that his book "can only be useful on condition of being methodical and containing no more than a Faculty professor can deliver, from memory, in his lectures." We should strongly recommend M. Micé, especially as he proposes to extend this plan to the entire domain of chemistry, to alter his title-page before again proceeding to publication. "Lecture Notes for Professors of Chemistry" would be a much more appropriate designation; less pretentious, certainly, but having the great advantage of accuracy. Undoubtedly, the author has succeeded in producing a rapport methodique; but it is decidedly not a rapport sur les progrès de lo Chimie organique pure, nor has it that nice adjustment between details and conciseness which is the essential requirement of such a treatise. The only work which fulfils and ably fulfils these conditions, is the German "Jahresbericht der Chemie," a model of patient and deliberate composition. M. Micé will find prefixed to it a list of some sixty or seventy periodicals, containing the various original papers to which it refers. We may fairly ask him whether many French professors (du haut enseignement) will be satisfied with the basis he has selected, viz., five French journals and the 3 rd edition of MM. Pelouze and Frémy's "Traité de Chimie." Considering that the author has had recourse to such a method of shortening his labours, it is not surprising that the performance should exhibit a generally hasty character. At p. II7, for example, we find the following passage: - "Théine gives up a quarter of its nitrogen, creatine a third, the other natural and artificial alkaloids one-half." It so happens that the experiments in this particular case, instead of being carried out with all nitrogenous organic bodies, were pardonably limited to nineteen instances. We regret we cannot commend this work, as fulfilling either the promise held out on its title-page, or the more limited intention expressed in its opening paragraphs.

History of Creation.-La Création d'aprés la Géologie et la Philosophie Naturelle. Par J. B. Rames. (Paris: Hachette.)

THIs is an odd book. Even in these days of sensational works on science we are not sure that, in his own style, M. Rames has been surpassed. His purpose is to describe in a kind of prose epic, the history of our planet and its inhabitants, from the nebulous condition of the solar system down to the present day. Apostrophising sun, moon and stars by turns, he tells them how they have been fashioned and of what uses they are. Tyrants and philosophers come in for appropriate addresses and then the writer plunges into the depths of the primeval ocean in which the Laurentian rocks were formed. He finds its waters hot, charged with silica and in the act of depositing crystalline rocks in the form of gneiss and schist. One day-whether in the depths of the thermal ocean, or in the lakes that dotted the lonely islets, he cannot tell- "Life, one of the special forms of solar heat pervading the universe like all the other natural forces, finds, for the first time upon our globe in little aggregations of inert matter, the conditions which allow of its manifestation, and thus rises dimly the dawn of an organic kingdom." The subsequent development of these primal germs into the complex genera and species of the animal and vegetable world, through its succeeding geological formations, forms the subject of the remaining portions of the book, of which, however, only the first part, reaching into the Permian period, is published. M. Rames seeks no adventitious aid from sensational pictures : not a single illustration occurs in his book. $\mathrm{He}$ trusts wholly to the powers of his pen and has certainly produced a lively, if not very trustworthy, narrative.-A.G.

\section{THE WORK OF THE SEA}

THE work done by the Sea is infinitely various, immeasurable in quantity and of inexpressible value to the inhabitants of the earth. It is the one ceaseless worker, never resting and ever accomplishing the tasks it has to perform. The land and the sea may appear to some to be for ever fixed and unalterable, and the map of the world represents to them the geography of the globe of 6,000 , or 60,000 years ago, the geography of to-day, and the geography of 60,000 years hence. Still not only does Geology show by the testimony of the far-distant past the impossibility of this being so; but it has been given to man to see and record the constant rising and falling of the land, within the periods of history and even to measure the movement with sufficient accuracy and such certainty as to enable him to venture predicting, to some extent, on the probable geograpliy of the future.

The Earth is born of the Ocean. Continents and islands rise out of the sea, new, luxuriant and vigorous; and like ourselves they grow, mature and do their appointed work; then wane and seem to die, though they do not die. They sink beneath the waves, apparently for ever ; but only to be regenerated, renewed, quickened into life and born again remodelled. And the sea-the invigorating and ever-toiling Mother-works this wonder.

Mons. Quenault, Sous-Préfet de Coutances, in a little book called "Les Mouvements de la Mer," has lately given us some exceedingly interesting facts, which he has gathered from old records, as well as from his own observation and other sources, respecting the sinking of the land and the encroachments of the sea on the coasts of Brittany, Normandy and other places on the western borders of France. Thus, in the Gulf of Cordouan at the mouth of the Gironde, the sea has advanced 730 metres, within twenty-eight years; the buildings on the Pointe de Grave have often been destroyed and rebuilt and the lighthouse is now removed, for the third time, more inland. The sea flows more than ten metres deep over what a short time since was a sandy beach. Twenty-five more years and the Atlantic will flow over the marshes of Soulac and Verdun; the Gironde will enter the sea by a second embouchure and the Isle of Cordouan, detached from the continent, will gradually become a mere rock.

The legends which are recounted among the population of Brittany lead one to think that many places in the neighbourhood of the coast-to-day immersed-were formerly above the level of the sea. In their native poetry and with their passion for the marvellous, the country people refer these facts to supernatural agency, where the Devil plays a prominent part. The bay of Douarnenez, where at high water the depth is considerable, is the site of a once flourishing city, the town of $Y_{s}$, the capital of Cornouaille. At the south side, when the tide is low, are distinguished clearly, five or six metres under water, Druidical remains, altars, portions of walls and ruins of various monuments. Again, on the opposite side, near Cape Chevre, they are to be found, though not so easily seen and not so numerous; but that they can be seen under favourable circumstances there is no doubt whatever. The fishermen there believe all the reefs and rocks in the bay to be portions of the ruins. In the r6th century, when the water in the bay was not so deep as now, the Canon Moreau was able then to follow the lines of a vast enclosure (enceinte) of masonry, and above the sand, in the shallower places, he discovered funeral urns, stone sarcophagi, \&c. The traveller Comby also adds, that after a storm which excavated and scooped out portions of the sands, one could perceive traces of elm trees, disposed with a regularity which shows that a plantation existed at this spot.

Submerged forests have been found on the coasts of Brittany and particularly in Finisterre, in the neighbourhood of Morlaix. There are historical documents to 
prove that at the bay of Mont Saint-Michel the coast has been submerged within a period subsequent to the Roman domination. Rouault, Cure de Saint-Pair, says :"About the year 400 there was in the Basse Normandie towards the west a large forest named Scicy, extending from the rocks of Chausey to the Mont de Tomba"-now Mont Saint-Michel. In the twelfth century the troubadour Guillaume de Saint-Pari referred to this submerged forest in a quaint bit of old French, which may be freely translated thus :-

\section{"Not far from Avianches, on Brittany's shore, \\ Quokelonde forest spread out of yore; \\ but that famous stretch of fertile land \\ Is hidden now by the sea and the sand, \\ No more will its venison grace the dish- \\ The ancient forest yields nought but fish."}

This forest of Scicy, or Scissiacum, was said to have been full of wild beasts-" "præbens altissima latibula ferarum"-and peopled by half-savage natives, to whom succeeded, in Christian times, a number of Anchorites who sought retirement there, far from the tumult of the

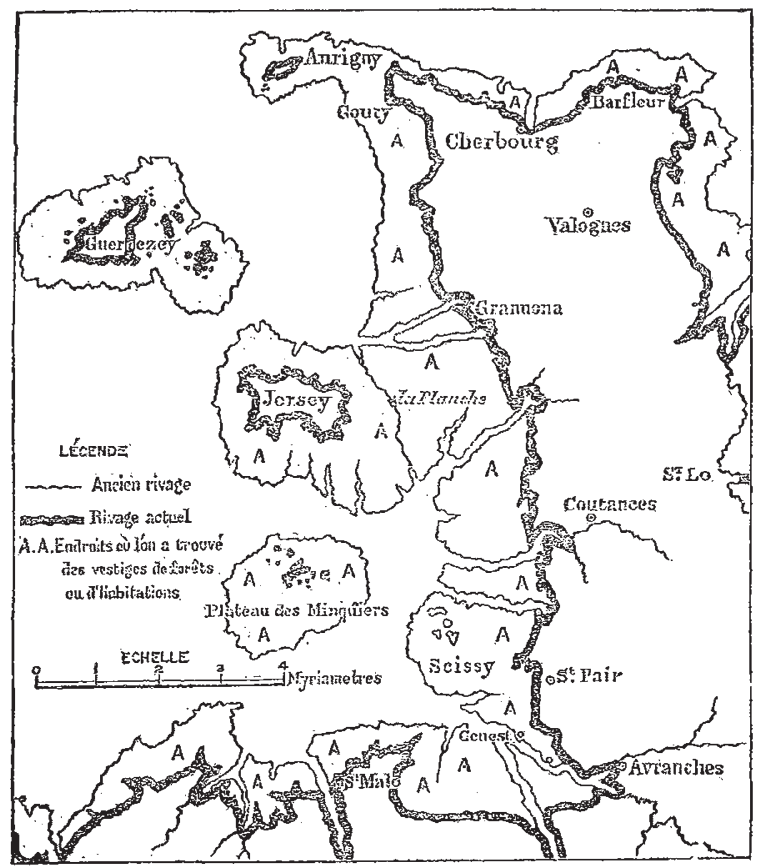

world. The parishes of St. Louis, Mauny and La Feuillette have disappeared beneath the waves since the I $3^{\text {th }}$ century. A story is told of a priest of the diocese of Dol, that, having in $\times 685$, learned by tradition that there was formerly, in the place then (and now) occupied by the sea, a parish named St. Louis, informed the Court of Rome that this living was vacant "per obitum." Upon this they consulted the registers and found actually that there had been presentations to this living by former Popes. A priest of Basse-Bretagne was therefore appointed and he departed at once to take possession. But on arriving in sight of Mont Saint-Michel, what was his surprise when he was shown on the sands and in the sea, the place where was formerly situated his pretended parish.

There is every reason to believe that the whole of the Channel Islands were, at one time, part of the mainland of France and there is positive proof of the island of Jersey having been so. There are certain existing manuscripts belonging to the monastery of Mont Saint-Michel, which tell us that, in the sixth century, the district of Jersey was separated from the mainland of Coutances by only a narrow rivulet, bridged by a single plank which the inhabitants were bound to keep in repair for the Archdeacon of the mother church to pass over on his periodical visitations. In the register of the taxes of the island, there is an entry referring to rents received from various persons for the privilege of allowing pigs to feed on the acorns in the forest of St. Ouen-now the bay of that name-but, M. Quenault's informant adds rather unnecessarily, "elles ne sont plus payées aujourd'hui!" There are also many other manuscripts quoted and instances given of the great alteration that has taken place in the outline of the Channel Islands and the coasts of France, of which there is given an exceedingly interesting map by $M$. Deschamps-Vadeville-a fac-simile of a chart copied in the year 1406 from one of a much older date. This map, which we reproduce in miniature, shows the coast line from Cape Finisterre down to St. Malo to have been, at that time, from six to twelve miles farther west than at present. The island of Jersey is part of a peninsula, ten or twelve miles wide, stretching out from the French coast to a point some three or four miles west of that island as it at present exists. Guernsey also is shown to have then been considerably larger than the Isle of Man now is. 'Throughout the whole area of this departed coast, are depicted the positions of some score of places where evidences of the existence of submerged forests have been discovered.

The sinking of the land which has taken place within the periods of history, has occurred only between the parallels of $10^{\circ} \mathrm{S}$. and $55^{\circ} \mathrm{N}$. lat. North of this, it is gradually becoming more and more elevated. Of this phenomenon $M$. Quenault gives an equally interesting and detailed account, with numerous facts and voluminous evidence which cannot be recounted within the limits of the present article. M. Quenault concludes-with regard to the depression of the land- "One gathers from all these evidences, that the movement, since the eighth century, has been about two metres a century. If it continues at the same rate for ten centuries more, the peninsula of Cotentin will be an island and all the ports of La Manche will be destroyed. Some centuries later and Paris will be a seaport, waiting only to be submerged in a score of centuries. Thus in a period, less than half as'long as that during which the pyramids of Egypt have braved theravages of time, Paris itself-if it is not burned down during one of the revolutions of its inhabitants, as amiable and spirituel as they are inconsistent-Paris will probably be engulphed in the Atlantic, a master before whom the intractable Parisian must haul down his flag. Let him take warning!"

Charles W. Whitaker

\section{MICROSCOPICAL INVESTIGATION OF METEORITES}

A PAPER on the above subject, forming part of an investiA gation commenced two-and-a-half years ago by its author, Prof. Maskelyne, of the British Museum, was read at a recent meeting of the Royal Society. We are indebted to the author for enabling us to lay before our readers the following full abstract of the paper:-

With a view to obtain some more satisfactory means of dealing with the aggregates of mixed and minute minerals, which constitute meteoric rock, the author sought the aid of the microscope, having in the first place sections of small fragments cut from the meteorites so as to be transparent. By studying and comparing such sections, one learns that a meteorite has passed through changes and that it has had a history of which some of the facts are written in legible characters on the meteorite itself and, one finds, that it is not difficult roughly to classify meteorites according to the varieties of their structure. One also recognises constantly recurring minerals; but the method affords no means of determining what these are. Even the employment of polarised light, so invaluable where a crystal of which the crystallographic 